\title{
TERAPÉUTICA PARA TRATAR EL CÓLERA EN YUCATÁN, MÉXICO (1833-1853). MEDICINA FISIOLÓGICA, HERBOLARIA LOCAL Y RÉGIMEN MORAL
}

\author{
Paola Peniche Moreno
}

Centro de Investigaciones y Estudios Superiores en Antropología Social, Unidad Peninsular (Mérida, Yucatán, México)

e-mail: ppeniche@yahoo.com

Recibido: 9 diciembre 2014; Aceptado: 20 enero 2016.

Cómo citar este artículo/Citation: Peniche Moreno, Paola (2016), “Terapéutica para tratar el cólera en Yucatán, México (1833-1853). Medicina fisiológica, herbolaria local y régimen moral”, Asclepio 68 (1): p133. doi:http://dx.doi.org/10.3989/asclepio.2016.12

RESUMEN: Este artículo analiza los pilares que sostuvieron la práctica terapéutica en Yucatán para tratar a los enfermos de cólera durante los brotes registrados antes del descubrimiento de su etiología bacteriana, uno en 1833 y otro en 1853. Debido en parte a una importante evolución del pensamiento médico-científico y a la divulgación de los principios del positivismo, en esta época se vivió un profundo proceso de transformación que significó, entre otras cosas, nuevas percepciones sobre la enfermedad y esquemas distintos a los coloniales para afrontar las emergencias y procurar la salud pública. Sin embargo, ante la falta de consensos en cuanto al origen del cólera y sus medios de propagación, el gobierno estatal promovió la difusión de diferentes técnicas terapéuticas empleadas en Europa o Estados Unidos, que se sumaron al conocimiento local respecto al empleo medicinal de la herbolaria, retomando también antiguas ideas sobre la incidencia de las conductas morales individuales en la propensión al contagio y eventualmente a la muerte.

PALABRAS CLAVE: cólera; historia de la medicina; terapéutica; herbolaria; Yucatán.

\section{THERAPY FOR THE TREATMENT OF CHOLERA IN YUCATAN, MEXICO (1833-1853). PHYSIOLOGICAL MEDICINE, LOCAL HERBALIST AND MORAL REGIMENT}

\begin{abstract}
This article analyzes the pillars that supported the therapeutic practice in Yucatán to treat cholera patients during the outbreaks preceding the discovery of its bacterial etiology, one in 1833 and another in 1853. Due partly to a significant evolution in scientific and medical ideas, and the dissemination of the principles of positivism, a profound process of transformation was experienced, which brought, among other things, new perceptions of the disease as well as schemes different from the colonials to deal with emergencies and ensure public health. However, given the lack of consensus about the origin of cholera and its means of propagation, the government promoted different therapeutic techniques practiced in Europe or the United States, alongside local knowledge on the medicinal use of herbs, while also reviving old ideas on the impact of individual moral behavior in the tendency to contract the disease and eventually die.
\end{abstract}

KEY WORDS: cholera; History of Medicine; therapy; herbalist; Yucatan.

Copyright: () 2016 CSIC. Este es un artículo de acceso abierto distribuido bajo los términos de la licencia Creative Commons Attribution (CC BY) España 3.0. 


\section{INTRODUCCIÓN}

El 16 de julio de 1833, Nicolás Uc, cacique del poblado maya de Nohcacab, escribió al gobernador del estado de Yucatán, México, que desde hacía diez días sufrían «el temible mal devorador nominado cólera» y que a pesar de haber tomado todas las medidas para impedir su voracidad y marcha, contaban ya varios contagiados y muertos. El alcalde del pueblo de Baca aseguró que en tan sólo tres días habían fallecido 29 personas por el mismo mal, observando que algunos «con sólo asistir a la agonía del atacado caen muertos sin esperanza de remedio». Las autoridades de Hunucmá afirmaron que a las haciendas de su jurisdicción el mal se había extendido «con toda su fuerza desoladora» sin poder saber el número exacto de muertos, porque «los mayordomos que tenían la orden de mandar diariamente las listas de los que han enterrado en sus respectivas haciendas, han sido casi los primeros que han fallecido ${ }^{1}$.

En efecto, de su origen asiático el cólera morbus llegó a Yucatán en 1833. Inauguró una nueva ruta de entrada a México en cuanto a microbios se refiere pues no llegó directamente desde Europa ni desembarcó en Veracruz, sino que procedente de Nueva Orleans descendió en el puerto de Campeche, también entrando al país a pie, por la frontera norte ${ }^{2}$.

Se trataba de una nueva patología en México. Los habitantes de Yucatán, como los de América y Europa, tenían breves noticias sobre sus efectos, desarrollo y desenlace. Tras la experiencia vivida en 1833, en 1853 la región enfrentó un nuevo azote de la misma enfermedad, ahora esparcida por tropas federalistas disidentes e indígenas sublevados de la Guerra de Castas ${ }^{3}$.

El contexto político y social en el que se vivieron estas dos epidemias fue particularmente convulso para Yucatán. Tras la declaración de Independencia, durante toda la primera mitad del siglo XIX, el estado vivió conflictos sucesivos entre federalistas y centralistas, experimentó varios sistemas de gobierno, revisó sus relaciones con la República, renovó su marco institucional, promulgó tres textos constitucionales (1825, $1841,1850)$, sin solventar los problemas sociales que estallaron con la sublevación indígena de 1847 que duró varias décadas. Por otro lado, también hubo una paulatina secularización de distintos ámbitos de la sociedad, dejando atrás el dominio de la Iglesia sobre muchos aspectos sociales, económicos y políticos, entre ellos las explicaciones sobre las enfermedades y el manejo de las emergencias epidémicas.
Quizá por el vínculo inestable con la federación y el continuo enfrentamiento político entre facciones referido líneas antes, los inicios de la profesionalización de la medicina en Yucatán, con la fundación de la Escuela de Medicina el 10 de junio de 1833, no se hicieron eco de la reforma en la educación emprendida por el vicepresidente Valentín Gómez Frías que llevó a la fundación del Establecimiento de Ciencias Médicas en octubre de 1833 (Rodríguez de Romo, 2000, p. 219). En la educación médica, se rompió con moldes tradicionales tomando como referencia a la Escuela de Medicina de París, cuyo modelo biológico lesional planteaba a la enfermedad como una alteración funcional de los órganos del cuerpo humano. En consecuencia, en el nuevo plan de estudios la anatomía y fisiología cobraron gran relevancia, y la cirugía se unió con la medicina para formar las "ciencias médicas» (Rodríguez de Romo, 2000, pp. 217-217; Rodriguez, 2001, p. 18). Sin embargo, Yucatán no tuvo que «romper» con antiguos modelos en la educación médica, porque no había tal antes de 1833, y los médicos que ejercían su profesión desde finales del siglo XVIII habían sido formados precisamente en la Escuela de París. El primer programa de estudios en Yucatán incluyó anatomía, fisiología, patología y medicina operatoria, entre otras cátedras, replicando las ideas médicas vigentes en Francia, pero conservando las cátedras de Prima y Vísperas que en otras partes se habían suprimido (Erosa Barbachano, 1997, p. 268). Tras su apertura, la Escuela de Medicina en el estado continuó con el mismo plan de estudios en medio de dos epidemias de cólera (1833 y 1853), continuos enfrentamientos entre facciones políticas y el estallido del conflicto armado conocido como la Guerra de Castas en 1847. No fue hasta 1869 que en Yucatán se promulgó la ley de Instrucción Pública del Estado y con ello se creó la Escuela Especial de Medicina, Cirugía y Farmacia, más acorde con la reforma emprendida décadas antes a nivel nacional (Erosa, 1997, p. 269).

Este artículo analiza los pilares que sostuvieron la práctica terapéutica en Yucatán para tratar a los enfermos de cólera durante las epidemias registradas antes del descubrimiento de su etiología bacteriana 4 . Se presiguen tres objetivos: 1) mostrar la compleja interrelación entre ideas y prácticas médicas a partir del estudio de la terapéutica; 2) considerar la base lógica de los tratamientos, y distinguir el papel de conocimiento y especies locales en el tratamiento de enfermedades; 3 ) revelar en qué medida las ideas científicas y médicas europeas incidieron en el proceso salud/enfermedad/atención, en una provincia de México con una fuerte tradición en medicina indígena. 
Se parte de una perspectiva de Historia Social que permite, a través de un enfoque relacional, comprender la imbricación, adaptación y transformación de distintos sectores de la sociedad, con sus propias prácticas e ideas relativas a la salud, pero vinculados coyunturalmente a través de las epidemias de cólera. De la antropología médica se retoma la noción del proceso salud/enfermedad/atención como un constructo histórico que se desarrolla y transforma en un espaciotiempo determinado, profundamente vinculado con la vida de un colectivo, sus prácticas culturales y formas de percibir el mundo (Menéndez, 1981, pp. 1213; Rosen, 2005, p. 50). En este proceso, los colectivos sociales acuden a diferentes «modelos, saberes y formas de atención y prevención de los padecimientos» con distintas técnicas diagnósticas y variados tipos de tratamiento y estrategias de curación (Menéndez. 2009, p.25) Pero esta coexistencia es dinámica, pues al entrar en contacto y relacionarse se modifican constantemente mediante la síntesis de concepciones y prácticas derivadas de diferentes saberes (Menéndez, 1994, pp. 72, 74; Campos-Navarro, 1997, p. 69).

Para desarrollar los objetivos propuestos, se acudió a fuentes primarias como literatura médica de la época, folletería, hemerografía y manuscritos en archivos locales. Se privilegió un tipo de selección y lectura que no se restringiera a Yucatán sino que permitiera ubicar al estado en contextos nacional e internacional, reconociendo distintos modelos y saberes, su difusión y concreción a nivel local.

\section{LA MEDICINA FISIOLÓGICA COMO ESQUELETO DE LA TERAPÉUTICA}

Desde la temprana época colonial, a Yucatán llegaron de Europa virus y bacterias lo mismo que ideas sobre el origen de las patologías, explicaciones sobre el funcionamiento de los órganos del cuerpo y prácticas médicas para conservar la salud y combatir la enfermedad. Las muy antiguas teorías humorales Ilegaron a América con los colonizadores españoles, y su aparente correspondencia con prácticas médicas de tradición indígena ha sido ampliamente discutida por distintos autores (Foster, 1987; Pérez-Tamayo, 1988, t. 1, p. 144) ${ }^{5}$.

Cuando el cólera apareció por primera vez en Europa, era tan ininteligible como lo fue la peste cinco siglos antes, y los recursos teóricos y prácticos de los médicos eran los mismos que los de sus predecesores medievales (Rosenberg, 1962, p. 226). Pero si bien el saber epidemiológico cambió poco desde tiempos hipocráticos, a partir del Renacimiento -y más en la primera mitad del siglo XIX - los médicos adoptaron nuevas actitudes: pusieron mayor atención en saber en qué consiste el hecho de la enfermedad epidémica y buscaron combatir y prevenir el morbo con recursos nuevos (Laín Entralgo, 1978, p. 314).

Desde su primera aparición en Europa en 1832 y hasta antes del descubrimiento de su etiología bacteriana, prevaleció la noción de que el origen del cólera (como de otras enfermedades epidémicas) se encontraba en un veneno o fermento transmitido por contacto directo con personas u objetos infectados, o a través de la atmósfera ${ }^{6}$. Los primeros en formular el concepto de "miasmas» como portadores de enfermedades epidémicas fueron Hipócrates y Galeno, idea relacionada con una constitución epidémica de la atmósfera corrompida por el clima u otras influencias atmosféricas o astronómicas (Baldwin, 2004, p. 2). Este paradigma constituyó el eje del conocimiento epidemiológico hasta ya entrado el siglo XIX.

Los miasmas se definían como «las partículas pútridas surgidas del fondo de la tierra que entran en contacto con el aire», o un "efluvio maligno que exhalan algunos cuerpos enfermos y generalmente las aguas corrompidas o estancadas» (Diario General, 1832, p. 616). Se pensaba que al entrar en contacto con mucosas, poros o piel, o por ingestión directa o indirecta, los miasmas podían provocar un desbalance interno de humores y afectar a los órganos del cuerpo humano. Estas ideas se sostenían a partir de aprensiones empíricas sobre el vínculo entre sitios fétidos y epidemias; especialmente frente al cólera que evidenciaba su asociación con aguas contaminadas, basura y excretas humanas (Rivals, 1834, p. 11; Corbin, 1987, p. 29; Palmer, 2003, p. 24).

En la prensa yucateca se tomó como ejemplo grandes urbes europeas como París, donde calles enteras como la contaminada Rue de la Mortellerie se habían contagiado de cólera en poco tiempo. Según el semanario El Baluarte, la suciedad de aquellas calles no era comparable con la que había en algunos rincones de la ciudad de Mérida, como en la calle Tiburcio que arrojaba incesantemente "miasmas mortíferos», de suerte que popularmente se le conocía como la calle «Tiburcio cloaca»". También se pensaba que los cuerpos enfermos o muertos eran igualmente metíficos; los primeros por sus desechos y emanaciones (eructos, borborigmos, ventosidades, vómitos, diarreas, etc.), y los últimos por su olorosa descomposición orgánica (Corbin, 1987, pp. 10, 28). El clima también era considerado como otra fuente de emanación de miasmas, especialmente donde había calor, humedad, pantanos, orillas de ciénagas o lagos ${ }^{8}$. 
Para la prevención, estas ideas fueron particularmente importantes porque a fin de evitar la extensión y voracidad de la epidemia, se buscó eliminar los focos de emanación de miasmas mediante la higiene, y evitar su transmisión a través del aislamiento o la purificación del aire (Rosenberg, 1962, pp. 72-73; Cipolla, 1993, pp. 18-19) ${ }^{9}$. Con este marco de ideas las autoridades enfrentaron en buena parte del siglo XIX epidemias como viruela, fiebre amarilla y cólera ${ }^{10}$.

La teoría miasmática convivió muchos siglos con la teoría humoral, pues la primera buscaba explicar la manera en que una enfermedad se transmitía entre la población, convirtiéndose en epidémica, y la segunda en el daño que causaba en el cuerpo el desequilibrio de humores.

La teoría humoral sobrevivió por más de catorce siglos revestida bajo diferentes disfraces pero conservando su estructura lógica. Constó de dos postulados básicos: a) el cuerpo humano está formado por un número variable pero finito de líquidos o humores diferentes; b) la salud es el equilibrio de los humores, y la enfermedad es el predominio de algunos de ellos. Los principales humores eran sangre, flema, bilis amarilla y bilis negra:

cuando cierto humor disminuye su concentración,

los síntomas corresponden a la ausencia de algo como sensación de vacío, mareo, pérdida de peso, etc.; el exceso o acumulación de cualquiera de los humores provocaba dolor, congestión o irritación. Esta teoría, además, postuló la existencia de un calor interno localizado en el ventrículo izquierdo del corazón, necesario al cuerpo para derivar los cuatro humores de los alimentos, mantenerlos en movimiento y conservar el equilibrio entre ellos (Pérez-Tamayo, 1988, t. 1, pp. 95-13).

El término con el que se designó al cólera tenía implícita la idea de la constitución humoral del cuerpo humano, compuesto por la locución latina morbus que significaba enfermedad y la voz griega chole que refería bilis.

La teoría humoral convivió con el desarrollo de la fisiología, entendida a partir del siglo XVIII como «el estudio científico de los movimientos y las funciones de los seres vivientes». El organismo se concebía como una composición de formas que integraban un «sistema móvil», y el movimiento de cada una de sus partes como un desplazamiento local. Por ello, la anatomía era una disciplina previa y distinta a la fisiología; era el estudio de las formas del organismo. La forma configuraba la función, y la función era el desplazamiento de la forma en el espacio; la fisiología se explicaba como una suerte de «anatomía impulsada» (Laín Entralgo, 1987, pp. 275-276).
En este marco de ideas, la enfermedad se entendía como un «desorden morboso del mecanismo que parece ser el cuerpo humano»; desorden de movimientos. Esa fue la definición de la patología llamada «iatromecánica»; para la cual la enfermedad era una disposición anómala de las fibras del organismo y de las relaciones mecánicas de éstas con los fluidos orgánicos. Así, el método anatomoclínico adquirió relevancia, ya que la lesión anatómica se convirtió en la clave para un diagnóstico y el fundamento de toda la patología (Laín Entralgo, 1978, pp. 286, 320-322).

Laín Entralgo (1978, p. 334) postula que mientras la iatromecánica fue un fenómeno de mayor difusión en los países católicos de Europa, la iatroquímica se desarrolló en los países protestantes. Sin embargo, para la primera mitad del siglo XIX la fisiología a nivel general registró una síntesis de ambos paradigmas, mezclada con importantes novedades empíricas de la anatomopatología (Laín Entralgo, 1978, pp. 325, 337).

La iatroquímica surgió a partir de la introducción en la medicina de nociones químico cualitativas. Los primeros iatroquímicos fueron anatomistas y anatomopatólogos defensores de la circulación sanguínea. Sus nociones sobre la estructura y dinámica de la materia viva se urdieron con las ideas de Paracelso sobre la fermentación y lo volátil. La fisiología iatroquímica tomó la fermentatio como una interpretación química de los procesos digestivos y la circulación de la sangre, conviertiéndola en un concepto clave para entender las formas biológicas sustanciales. De esta manera, se explicó que la digestión es una actividad fisiológica fermentativa y, por tanto, química, teniendo como agentes principales a la saliva, la bilis y el jugo pancreático (Laín Entralgo, 1978, p. 332).

En el siglo XIX la fisiología alcanzó su «mayoría de edad», convirtiéndose en la segunda "ciencia básica» de la medicina, precedida sólo por la anatomía. Entre 1800 y 1850 la fisiología francesa fue vitalista; es decir, estableció la diferencia entre lo viviente y lo no viviente sobre la hipótesis de la existencia de un principio vital, entendido como una fuerza específica (química o mecánica) activa en los seres vivos y superior a las fuerzas de la naturaleza. Se postuló que esta fuerza vital era común a todos los seres vivos, y así la patología vitalista francesa explicaba que el movimiento del cuerpo y sus partes -regido por una fuerza internase veía amenazado por fuerzas externas (como miasmas). Francia fortaleció estas hipótesis en la primera mitad del siglo XIX y así las enseñó al mundo (Laín Entralgo, 1978, pp. 345, 351, 438, 439, 442, 466). 
En este marco, el médico francés Joseph Victor Broussais propuso una «medicina fisiológica» basada en el concepto de «irritación». A partir de la afirmación anatomopatológica de que en casi todos los cadáveres era posible hallar lesiones de gastroenteritis, planteó la existencia de una irritación anormal del tubo digestivo provocada por causas externas (agua, frío, calor, fuego, etc.), causando una abundancia extraordinaria de sangre (hiperemia), gastroenteritis primaria y un consecuente daño generalizado por simpatía en otras partes del organismo. Desde esta perspectiva, la patología no era extraña al funcionamiento del ser vivo, pues los síntomas eran «el grito de dolor de los órganos sufrientes» (Arquiola, 1992, pp. 203206). Al reducir todas las enfermedades a un proceso de irritación, particularmente de la mucosa gastrointestinal, Broussais propuso una práctica terapéutica contundente para casi todos los padecimientos, incluyendo al cólera (Broussais, 1832). Su tratamiento se basaba en un régimen antiflogístico a partir de debilitantes, principalmente la flebotomía (Rolleston, 1939, p. 411). Algunos historiadores consideran que, en toda la historia de la terapéutica, no existe un capítulo más grotesco que el del tratamiento del cólera: al vómito persistente se administraban vomitivos, se exacerbaba la diarrea con purgantes y se practicaban sangrías a pacientes debilitados que necesitaban sangre (Howard-Jones, 1972, p. 373; Kiple, 1985, p. 173).

Este esquema fue de gran éxito en la medicina europea hacia 1830 (Laín Entralgo, 1978, p. 467); pero también se difundió por América entre 1820 y 1840, y su impacto fue sustancial en las terapéuticas empleadas para tratar a los enfermos de cólera durante casi todo el siglo XIX (Miqueo, 1987, p. 176).

Las hipótesis y prácticas médicas desarrolladas en Francia llegaron a Yucatán por medio de médicos que se formaron ahí y llegaron a ejercer en el estado desde los primeros años del siglo XIX, formando nuevas generaciones de facultativos e influyendo de formas decisivas en las nuevas políticas de salud pública gestadas al amparo de los gobiernos liberales. Destaca el Dr. Alejo Dancourt, originario de Francia y titulado en Medicina por la Escuela de París, que llegó a Mérida en 1802; dos años después fue designado "conservador» de la vacuna antivariolosa de la recién fundada Junta Provincial de Vacunación y más tarde fungió como rector de la Universidad (Erosa, 1997, pp. 22-23). En 1832 fue nombrado, junto con otros médicos, miembro de la Comisión Permanente de la Junta de Sanidad del Estado, que un año después sería la entidad responsable por dirigir la política de salud pública para enfrentar la pandemia del cólera ${ }^{11}$. Sobresale también el Dr. Ignacio Vado Lugo, originario de Guatemala, quien después de haberse graduado también en París llegó a Yucatán en 1833 donde pronto se involucró en las tareas de prevención contra el cólera y luego en la atención a enfermos; paralelamente participó como director de la recién fundada escuela de medicina ${ }^{12}$. En 1853 , después de haber redactado un método curativo contra el cólera morbus, falleció de esta enfermedad (Osorio y Carvajal, 1977, p. 285).

En efecto, cuando se vivió la primera epidemia de cólera en el estado, muchos de los facultativos que tenían permiso oficial para ejercer la profesión médica se habían formado en Europa, cuando más auge tenía la propuesta de la Medicina Fisiológica del Dr. F.J.V. Broussais. Consecuentemente, los médicos en Yucatán siguieron dos tipos generales de tratamiento: revulsivos y antiflogísticos. Ambos buscaban reestablecer la proporción de los humores y revertir los efectos dañinos de este supuesto desequilibrio en órganos específicos, como la irritación. Dentro de los tratamientos revulsivos, se cuentan vomitivos, lavativas y purgantes; en teoría estos procedimientos tenían la cualidad de eliminar los humores que se encontraban en exceso ${ }^{13}$.

Las terapias antiflogísticas buscaban disminuir la irritación patológica. Su principal técnica era la flebotomía, basándose en la idea de que la circulación normal de la sangre mantenía la digestión activa y las evacuaciones normales, en tanto que una variación (provocada por una alteración de los humores) tenía el efecto de irritar el estómago, provocando espasmos y dañando al resto de los órganos internos (PérezTamayo, 1988, t.2, p. 20; Buzzi, 1968, p. 159). El de barberos/sangradores o flebotomistas era un oficio característico de la práctica empírica de la medicina desde siglos anteriores, y trabajaban como artesanos que entre otras cosas sacaban muelas, ponían ventosas y realizaban sangrías (Amezcua, 1997, pp. 31-36; Ortiz, 2004, pp. 35-38; Expósito, 2011, pp. 32-38).

Durante las dos epidemias de cólera, en 1833 y 1853, el gobierno yucateco a través de la Junta General de Sanidad contrató "sangradores» o "barberos inteligentes» que se encargaran de aplicar ventosas y sangrar a los enfermos. Esta Junta tenía una nómina vigente de flebotómanos, de donde se eligieron los que se consideraban "más diestros» para realizar curaciones ${ }^{14}$. El 14 de julio de 1833, el cabildo de Mérida convino el reclutamiento sangradores de los cuales nombró uno para el servicio de cada hospital provisional (cuatro en total) y otros tantos que atendieran el centro, turnándose semanalmente por grupos de cuatro. Se les autorizó un pago mensual de 10 pesos y su 
principal obligación era aplicar sangrías a los enfermos de cólera ${ }^{15}$. En caso de que tuvieran que salir durante su turno, debían fijar carteles en las puertas de sus casas, a fin de que se les ubicara en todo momento ${ }^{16}$. La manera específica en que debían realizar las curaciones era indicada por los facultativos autorizados por la Junta General de Sanidad; para la epidemia de 1853, por ejemplo, el Dr. Ignacio Vado indicó sangrías de 12 onzas para cuerpos robustos (Vado, 1853).

En el siglo XIX la flebotomía se hacía empleando básicamente tres técnicas: incisiones en venas o arterias, aplicación de sanguijuelas y ventosas. Las sangrías realizadas quirúrgicamente, hacían incisiones en dos venas: la yugular derecha para enfermedades consideradas «internas», y la izquierda para las «externas». Dependiendo del órgano que se quisiera curar, los cortes se realizaban en cabeza, cara y cuello; extremidades superiores y vientre; o extremidades inferiores (Fernández, 1794, pp. 141-143). Específicamente para el cólera, los cortes eran en el brazo ${ }^{17}$.

Las ventosas se consideraban un método menos agresivo que las escarificaciones en venas. A su favor se afirmaba que «no son peligrosas y su efecto es prontísimo", por lo que se practicaban cuando las sangrías se contraindicaban por la debilidad extrema del paciente. Se sostenía que su efecto curativo se debía a que "extraen una parte de la superabundante sangre y la atraen a la parte que se desea». El procedimiento finalizaba con una pequeña incisión para extraer el humor acumulado. Se podía aplicar en cualquier parte del cuerpo, dependiendo del sitio que se quisiera sanar (Fernández, 1794, pp. 148-155).

Otra forma de extraer sangre del cuerpo era mediante la aplicación de sanguijuelas ${ }^{18}$. Este hectoparásito, como huésped, se alimenta de la sangre de otro animal al que se adhiere mediante una ventosa $y$, mientras succiona su sangre, segrega anticoagulantes, vasodilatadores y anestésicos (Vera, Blu y Torres, 2005). Las sanguijuelas de uso medicinal debían reunir ciertas características para evitar aquellas ponzoñosas, como que se hubieran criado en agua dulce y corriente; que fueran delgadas y largas, de cabeza pequeña, color del dorso verde con rayas amarillas y el vientre encarnado; de esas se seleccionaban las más pequeñas. No obstante, se entendía que «aún estas tienen siempre algo de veneno», por lo que debían tenerse en un frasco de vidrio desde dos o tres meses antes de ser aplicadas, cambiándoles constantemente el agua para que de esa forma quedaran «purificadas». Unas horas antes de usarse se sacaban del agua para que, hambrientas, se adhirieran al cuerpo con más fuerza (Fernández, 1794, pp. 162-163).
El empleo de sanguijuelas fue muy extendido en la medicina pre-pasteuriana, especialmente en la primera mitad del siglo XIX con el auge de la «medicina fisiológica». En consecuencia, las poblaciones naturales de sanguijuelas se vieron fuertemente mermadas, particularmente en Inglaterra y Francia. Para satisfacer la demanda creciente, se exportaron grandes cantidades de sanguijuelas de un país a otro, tanto que en 1823 Inglaterra dictó normas para controlar su tráfico; Rusia, por su parte, estableció temporadas de colectas para evitar su extinción (Buzzi, 1968, p. 159). En México las sanguijuelas también fueron muy utilizadas en el siglo XIX ${ }^{19}$. En los escritos médicos mexicanos de esta época se registran especies procedentes del Valle de México, Querétaro, Tehuacán y del pueblo de Ixmiquilpan (Jiménez, 1856, pp. 483-485). Para su recolección, los indios se introducían semidesnudos hasta los muslos en acequias y canales e iban recogiendo todas las que se les pegaban al cuerpo, y se transportaban en recipientes de barro cubiertos con lodo y yerbas (Ramos de Viesca, et al., 2002, p. 57). Su uso en caso de cólera fue muy recomendado en el país, según los diversos métodos curativos de distintos lugares como Ciudad de México, Michoacán, Tlaxcala, San Luis Potosí y Yucatán (Febles, 1833, p. 7; Zavala, 2007, p. 54; Alcalá, 2008, p. 164; Netzahualcoyotzin, 2011, p. 68). Se entendía que estos gusanos, al extraer sangre, tenían efectos desinflamatorios en el estómago, pero también se empleaban en las sienes para disminuir el dolor de cabeza que acompañaba al cólera y evitar una posible «congestión cerebral» (Canú, 1848, p. 8). Existen referencias de que, en efecto, la aplicación de sanguijuelas fue especialmente recurrida para la epidemia de cólera de 1850 en el Valle Central (Jiménez, 1856, p. 487).

\section{MÉTODOS CURATIVOS Y PRÁCTICA MÉDICA}

La terapéutica para el cólera incluyó diversas sustancias químicas, minerales o botánicas que se administraban en formas variables según las fases identificadas de la enfermedad. Cada facultativo recomendaba o seguía alguna receta o método en particular, pero todos buscaban los mismos efectos: purgar al cuerpo del exceso de humores, restablecer la circulación regular de la sangre, tranquilizar al sistema nervioso cerebral, excitar a sistema nervioso ganglionario, disminuir la irritación de los órganos internos y rehabilitar su buen funcionamiento. Las diferencias entre métodos estribaban en la manera y cantidades para mezclar sustancias parecidas, orgánicas y/o inorgánicas. Los procedimientos terapéuticos indicados en todos los métodos curativos impresos (Tabla 1) que circularon en el estado incluyeron la administración de sustancias de la mano de otras técnicas como sangrías, masajes y «friegas» o "frotaciones», baños de vapor, etc. 
Tabla 1. Impresos que circularon en Yucatán y Campeche sobre el cólera, 1832-1853.

\begin{tabular}{|c|c|c|c|}
\hline Autor & Año & Texto & Fuente \\
\hline $\begin{array}{l}\text { Alejo Dancourt y } \\
\text { Juan Hübbe }\end{array}$ & 1832 & $\begin{array}{l}\text { Dictamen de la Junta General de Sanidad del Es- } \\
\text { tado de Yucatán sobre la epidemia de Cholera } \\
\text { Morbo que se imprime de orden del gobierno del } \\
\text { mismo estado }\end{array}$ & Campeche, Imprenta del Huracán \\
\hline Juan Hübbe & 1832 & $\begin{array}{l}\text { Memoria sobre el modo de comunicarse el cólera } \\
\text { morbo }\end{array}$ & $\begin{array}{l}\text { Mérida, Yucatán, Imprenta de Lorenzo } \\
\text { Seguí. (apud. Saldaña. Las revoluciones } \\
\text { políticas, t. 1, p. 226.) }\end{array}$ \\
\hline - & 1848 & Disminución de los estragos del cólera morbus & $\begin{array}{l}\text { En El Fénix, Campeche, } 15 \text { de diciembre } \\
\text { de } 1849, \text { No. } 10 .\end{array}$ \\
\hline Canú & 1848 & $\begin{array}{l}\text { Remedios preservativos y curativos contra el có- } \\
\text { lera morbus }\end{array}$ & $\begin{array}{l}\text { Mérida, Impreso por Joaquín Castillo } \\
\text { Peraza (apud. Alcalá, Sanidad, p. 311) }\end{array}$ \\
\hline Canú & 1848 & Remedio contra el cólera & $\begin{array}{l}\text { Publicado originalmente en el Morning } \\
\text { Post y reproducido en El Fénix, Campeche, } \\
25 \text { de noviembre de } 1848 \text {, Número } 6 .\end{array}$ \\
\hline- & 1848 & $\begin{array}{l}\text { Descubrimientos contra el cólera morbo intere- } \\
\text { santes al pueblo }\end{array}$ & $\begin{array}{l}\text { Campeche, Imprenta G. Buenfil (apud. } \\
\text { Alcalá, Sanidad, p. 311) }\end{array}$ \\
\hline $\begin{array}{l}\text { Francisco Ramos } \\
\text { Borguella }\end{array}$ & 1848 & El Cólera y el magnetismo & $\begin{array}{l}\text { En El Fénix, Campeche, } 20 \text { de noviembre } \\
\text { de 1848, número } 5 .\end{array}$ \\
\hline Dr. Foy & 1849 & $\begin{array}{l}\text { El cólera-morbus. Primeros socorros que deben minis- } \\
\text { trarse a los coléricos antes de la llegada del médico, } \\
\text { procedidos de una indicación precisa de los síntomas } \\
\text { de la enfermedad, y seguidos de una exposición sen- } \\
\text { cilla y rápida de los medios higiénicos y profilácticos } \\
\text { que puedan impedir su ataque }\end{array}$ & $\begin{array}{l}\text { Médico francés que escribe a petición } \\
\text { del redactor del periódico El Fénix, Cam- } \\
\text { peche, septiembre de 1849, números del } \\
62 \text { al } 66 .\end{array}$ \\
\hline Desruelle & 1849 & Tratamiento del cólera & $\begin{array}{l}\text { Traducción de un texto escrito en París } \\
\text { el } 31 \text { de marzo de } 1849 \text { y publicado en El } \\
\text { Fénix, } 15 \text { de julio de } 1849 \text {, número } 52 \text {. }\end{array}$ \\
\hline FF.Quin & 1850 & Cura homeopática del Cólera & $\begin{array}{l}\text { Traducido y reimpreso en Mérida por Naza- } \\
\text { rio Novelo [en CAIHY VII/1850/01 folletería] }\end{array}$ \\
\hline- & 1850 & $\begin{array}{l}\text { Descubrimientos contra el cólera morbo intere- } \\
\text { santes al pueblo }\end{array}$ & $\begin{array}{l}\text { “Copiado de varios periódicos" [en CAI- } \\
\text { HY, VII/1850/01 folletería] }\end{array}$ \\
\hline Pedro Vázquez & 1850 & Método curativo del cólera morbo & $\begin{array}{l}\text { Impreso en Sevilla, pero disponible en } \\
\text { CAIHY, VII/1850/01 folletería }\end{array}$ \\
\hline $\begin{array}{l}\text { Cristóbal } \\
\text { Hernández }\end{array}$ & 1850 & $\begin{array}{l}\text { Medidas sanitarias adoptadas por el ayuntamien- } \\
\text { to de Mérida para el caso de que el cólera morbus } \\
\text { invada esta capital }\end{array}$ & Mérida (apud. Alcalá, Sanidad, p. 311) \\
\hline Ignacio Vado & 1853 & $\begin{array}{l}\text { Método curativo contra el cólera morbo sin nece- } \\
\text { sidad de médicos ni botica }\end{array}$ & Mérida, Imprenta de Mariano Guzmán \\
\hline Ignacio Vado & 1853 & $\begin{array}{l}\text { Disertación sobre el método curativo del Cólera } \\
\text { Morbus por el vómito provocado por medio del } \\
\text { agua fresca }\end{array}$ & $\begin{array}{l}\text { Boletín Oficial Núm. } 245 \text { (apud. Laviada- } \\
\text { Arrigunaga, El tratamiento del cólera, } \\
\text { 1993, p. 98) }\end{array}$ \\
\hline
\end{tabular}

Desde 1832 el gobierno de Yucatán decretó la «libertad» de adoptar el método que se creyera más conveniente ${ }^{20}$. En los pueblos los religiosos asistían a los enfermos administrándoles remedios terapéuticos, lo mismo que auxilios espirituales. Con segu- ridad localmente se acudía también a lo que hoy se conoce como «médicos tradicionales», pero al actuar independientemente de la estructura (más o menos) formal de sanidad, sus procedimientos no quedaron registrados en papel ${ }^{21}$. En contraste, subsisten en el 
Archivo General del Estado de Yucatán informes de párrocos detallando cómo en 1833 atendieron a los enfermos de cólera en sus respectivas jurisdicciones (Tabla 2). Por disposición oficial, las juntas de sanidad locales quedaron obligadas de enviar al gobierno esta información y otros asuntos relacionados con la epidemia, como números de contagiados y muertos y medidas de prevención implementadas.

La Junta de Sanidad del pueblo de Xul, por ejemplo, dirigió un escrito a la Junta General de Sanidad, incluyendo cifras de enfermos y óbitos así como «el método curativo con el que el párroco administra a los enfermos con medicinas, alimentos y cuanto necesitan para el socorro de sus enfermedades». En esta localidad, como en muchas otras, era el cura quien aplicaba "los remedios tanto de yerbas conocidas como medicinales como los de botica» ${ }^{22}$. Por ello, a las cabeceras parroquiales (residencia de los religiosos) acudía gente de pueblos anexos y haciendas en busca de ayuda. Así fue que en Tizimín se socorrió a personas de Kikil, Espita y la Hacienda Culucmul, las cuales recibieron del párroco local «instrucciones» sobre cómo asistir a sus enfermos ${ }^{23}$.

A falta de párrocos, en algunos pueblos se nombraron "comisionados practicantes» que debían visitar localidades para instruir a sus habitantes sobre métodos curativos. No en todos los lugares fueron bien recibidos: las autoridades locales de Teabo informaron que en Chumayel se registraron algunos «desórdenes» entre los indígenas, como negarse a dar la dieta recomendada por los comisionados practicantes, rechazar la aplicación de cualquier medicina e, incluso, "en las más de las casas de estos [indígenas] les agarraban a garrotes [a los comisionados] para corretearlos» ${ }^{24}$.

En la información proporcionada por los curas, destaca el uso medicinal de especies locales que todavía hoy son empleadas en padecimientos estomacales, como hojas de naranja agria, kantunbub (o sanguinaria), pozol (o agua de maíz), epazote, chile habanero y hierbabuena.

Tabla 2. Remedios utilizados contra el cólera por distintos curas de pueblos de Yucatán (1833).

\begin{tabular}{|c|c|c|}
\hline Fórmula & Manera de administrarse & Efectos esperados \\
\hline \multicolumn{3}{|l|}{ Cura de Maní } \\
\hline \multicolumn{3}{|l|}{$\begin{array}{l}\text { Bebida caliente de hojas tiernas de naranjo } \\
\text { agrio }\end{array}$} \\
\hline \multicolumn{3}{|l|}{ Cura de Xul } \\
\hline Cocimientos de sanguinaria o kantunbub & Beber regularmente & Provocar sudor \\
\hline $\begin{array}{l}\text { Agua de maíz con hierbabuena, toronjil o } \\
\text { epazote }\end{array}$ & Beber después de sudar & \\
\hline $\begin{array}{l}\text { Cocimiento de cáscara de granada, } 6 \text { gotas de } \\
\text { tintura tebaica }\end{array}$ & Beber & Contener diarrea blanquecina \\
\hline $\begin{array}{l}\text { Chile habanero con sal y cocimiento de } \\
\text { sanguinaria }\end{array}$ & $\begin{array}{l}\text { Comer y beber } \\
\text { alternadamente }\end{array}$ & Contener diarrea blanquecina \\
\hline Cocimientos de cogollo de naranjo agrio & Beber & $\begin{array}{l}\text { Combatir "engarrotamiento de } \\
\text { extremidades" }\end{array}$ \\
\hline \multicolumn{3}{|l|}{ Cura de Tizimín } \\
\hline $\begin{array}{l}\text { Cocimiento de hojas de naranjo agrio con } 2 \\
\text { cucharadas de "balsamito" }\end{array}$ & En baño de vapor y para beber & \\
\hline $\begin{array}{l}\text { Espíritu de hierbabuena, entre } 12 \text { y } 30 \text { gotas } \\
\text { de tintura tebaica }\end{array}$ & Beber & Entrar en calor \\
\hline $\begin{array}{l}\text { Caldo de limón tripulado con vinagre, sal y } \\
\text { agua tibia }\end{array}$ & & \\
\hline
\end{tabular}

Fuente: AGEY, Poder Ejecutivo, Correspondencia Oficial, Vol. 3, exp. 15 
La publicación de métodos profilácticos y curativos constituyó una forma de prevención contra la amenaza que representaba la epidemia. Desde 1833, el gobierno de Yucatán dispuso que se publicaran en la prensa local algunos de los métodos curativos cuya "efectividad» fuera conocida. Si bien entre 1832 y 1833 fueron gran cantidad los que se difundieron en Europa y Estados Unidos, algunos en México, la única información sobre la terapéutica contra el cólera que se empleó en Yucatán durante la primera epidemia de cólera procede de la correspondencia oficial entre los ayuntamientos y el gobierno del estado. Una década después comenzaron a circular en la prensa local traducciones de métodos curativos originalmente escritos en otros idiomas.

A un año de haberse declarado en Yucatán la hoy llamada Guerra de Castas, el intelectual e impresor yucateco Joaquín Castillo Peraza tradujo al español y publicó en su imprenta el método contra el cólera del Dr. Canú (Tabla 3). Se temía que el conflicto trajera consigo una nueva epidemia de aquella «enfermedad aterradora y temible». Esta difusión de iniciativa privada buscaba contribuir a que, en caso de emergencia, los enfermos fuesen atendidos de manera inmediata salvando la gran carencia de facultativos. El método del Dr. Canú circuló originalmente en la prensa de Londres y luego fue traducido y replicado en otros lugares como España y Estados Unidos ${ }^{25}$.
Un año después el periódico liberal campechano El Fénix publicó en uno de sus números una nota titulada Disminución de los estragos del cólera morbus en la que se incluyen consejos terapéuticos, además de explicaciones sobre el cólera, su marcha mundial y métodos preventivos (Tabla 4). El autor reconoce haber tomado información de varios periódicos de Londres, San Petesburgo, Hamburgo, Ámsterdam y París.

En 1849 la amenaza de una nueva epidemia en Yucatán cobraba más fuerza; mientras que en el estado se vivía un serio conflicto bélico, corrían infaustas noticias del asolador paso del cólera por La Habana y Nueva York. En ese contexto, en la prensa campechana se publicó la traducción de un texto del Dr. Foy sobre el cólera morbus, originalmente redactado para el periódico liberal de México EI Siglo XIX (Foy, 1849).

Este texto contiene «consejos» dirigidos a la «gente común» para que, sin un facultativo especializado (Tabla 5), se enfrentara al cólera en caso de una nueva epidemia. El Dr. Foy era un prominente físico de Varsovia que atestiguó en dos ocasiones los estragos de la epidemia:

en 1831 en su natal Polonia y en 1832 en Francia. Adoptó una postura fervientemente anticontagionista; fue incluso de aquellos que para rebatir la posibilidad de que la epidemia fuera contagiosa, se inyectó sangre de personas infectadas (Bourdelais, 2006, p. 54).

Tabla 3. Remedios preservativos y curativos contra el cólera morbus del Dr. Canú (1847).

\begin{tabular}{|l|l|l|}
\hline \multicolumn{1}{|c|}{ Fórmula } & \multicolumn{1}{|c|}{ Manera de administrarse } & \multicolumn{1}{c|}{ Efectos esperados } \\
\hline $\begin{array}{l}1 \text { cucharada de mostaza, } 2 \text { de sal, } 1 / 2 \\
\text { azumbre de agua tibia }\end{array}$ & $\begin{array}{l}\text { Al principio de la enfermedad: cada 10 } \\
\text { minutos beber 1/3 parte }\end{array}$ & Provocar el vómito \\
\hline $\begin{array}{l}1 \text { vaso de aguardiente con agua y } 30 \\
\text { gotas de tintura de opio }\end{array}$ & Después de haber vomitado & \\
\hline $\begin{array}{l}1 \text { píldora de } 5 \text { granos de calomel y 2 } \\
\text { de opio }\end{array}$ & Cada 2 horas & Vaciar la bilis en la secreción \\
\hline $\begin{array}{l}2 \text { onzas de greda, } 4 \text { onzas de azúcar } \\
\text { blanco, polvo de canela u otro aromá- } \\
\text { tico, } 1 \text { onza de tintura de cachunde, } 1 \\
\text { grano de opio, 2 granos de sal volátil, } \\
\text { 1/2 azumbre de agua de menta con } \\
\text { pimienta }\end{array}$ & $\begin{array}{l}\text { 1 cucharada después de cada evacua- } \\
\text { cionca }\end{array}$ & \\
\hline Trementina caliente con láudano & Fricciones en el abdomen & Contrarrestar los cólicos \\
\hline $\begin{array}{l}\text { Infusión de jengibre con } 5 \text { gotas de } \\
\text { cloroformo }\end{array}$ & Después de las fricciones & Contrarrestar los cólicos \\
\hline $\begin{array}{l}\text { Agua caliente con azúcar y aguardien- } \\
\text { te, } 1 \text { cucharada de infusión de jengibre } \\
\text { o sal volátil }\end{array}$ & Periodo ascendente de la enfermedad & \\
\hline
\end{tabular}

Fuente: Canú, Remedios preservativos y curativos, 1849. 
Tabla 4. Remedios indicados en Disminución de los estragos del cólera morbo (1848).

\begin{tabular}{|l|l|l|}
\hline \multicolumn{1}{|c|}{ Fórmula } & \multicolumn{1}{|c|}{ Manera de administrarse } & \multicolumn{1}{c|}{ Efectos esperados } \\
\hline Harina de mostaza con vinagre & $\begin{array}{l}\text { Cataplasmas sobre el estómago, } \\
\text { renovándose cada 15 minutos }\end{array}$ & Sudorífico \\
\hline $\begin{array}{l}\text { Bebida ligeramente opiada con 2 cucharadas de extracto } \\
\text { de hierbabuena o aguardiente }\end{array}$ & Beber cada 3 o 4 horas & \\
\hline Sulfato de Sodio (Sales de Glauber) & & Catártico \\
\hline Sulfato de magnesio (Sales de Epson o Polvos de Sedlitz) & & Catártico \\
\hline Cocimiento de coloquintida & Beber & Catártico \\
\hline Cocimiento de aloe & Beber & Catártico \\
\hline
\end{tabular}

Fuente: “Disminución de los estragos del cólera morbus”, en: El Fénix, Periódico político y mercantil, Campeche, viernes 15 de diciembre de 1848, no. 10

Tabla 5. Remedios indicados en El cólera-morbus del Dr. Foy (1849)

\begin{tabular}{|l|l|l|}
\hline \multicolumn{1}{|c|}{ Fórmula } & \multicolumn{1}{c|}{ Manera de administrarse } & \multicolumn{1}{c|}{ Efectos esperados } \\
\hline $\begin{array}{l}\text { Infusión ligera y caliente de tila, manzanilla, hojas } \\
\text { de naranjo, toronjil, hierbabuena o sábila }\end{array}$ & Beber cada 15 minutos & Corregir dificultades en la orina \\
\hline Gajos de naranja o trocitos de hielo & Chupar & Disminuir la sed \\
\hline Agua de arroz endulzada con jarabe de membrillo & 1 o 2 tacitas cada 8 o 10 minutos & Combatir vómito y diarrea \\
\hline Agua caliente con una cucharada de almidón & Lavativas & Combatir vómito y diarrea \\
\hline
\end{tabular}

Fuente: Foy, “El cólera-morbus", en: El Fénix, Periódico mercantil y político, Campeche, 5 de septiembre de 1849, No. 62 al 66.

El único método curativo escrito en Yucatán fue el del Dr. Ignacio Vado Lugo, quien -como ya se dijoestuvo involucrado en las tareas de prevención y atención a los enfermos de cólera desde la primera epidemia de 1833. Recién llegado a Yucatán fue el facultativo responsable del hospital provisional del cuartel de Santa Ana y meses después fue nombrado director de la nueva Escuela de Medicina de la Universidad de Yucatán ${ }^{26}$. En 1832 fue testigo presencial de la invasión del cólera en París, donde se encontraba terminando sus estudios de medicina.

Después de redactar en 1850 su Higiene y moral razonadas, y frente a la inminencia de una nueva epidemia de cólera, la Junta Suprema de Sanidad del Estado le encargó un breve ensayo que orientara «al público» respecto a la manera de atender a los enfermos sin la necesidad de especialistas. Su escrito, titulado Método curativo contra el cólera morbo, sin necesidad de médicos ni botica se divide en dos partes: en la primera se abordan estrategias de prevención y en la segunda procedimientos terapéuticos.

En cuanto a la prevención, las recomendaciones del Dr. Vado están a tono con las concepciones de la época sobre el cuerpo, la salud individual y colectiva, y la enfermedad: aseo individual y de espacios colectivos y/o públicos, cuidado del comportamiento y moral personales, alimentación y vestidos adecuados.

Si bien no niega el papel de los miasmas en la transmisión del cólera, destaca su opinión de que la mejor protección era el total aislamiento. Detalla los síntomas característicos de la enfermedad para que la gente la identificara y actuara de manera inmediata, pues se consideraba que de ello dependía la vida de los atacados.

Para la preparación de este método, el Dr. Vado se valió de lo que observó en Francia durante la epidemia de cólera en 1832, así como también de los resultados obtenidos con la terapéutica que él mismo aplicó durante la epidemia de 1833 en Yucatán. Esta experiencia, sumada a su formación como médico en Europa, le permitió conjuntar en su escrito concepciones propias de la medicina humoral, métodos fisiológicos y condiciones regionales específicas a tomar en cuenta para la recuperación. Cuando aborda la alimentación, por ejemplo, previene sobre ciertas "frutas indigestas» como aguacate, mango o chico zapote, todas especies locales. Cuando en los métodos escritos para el viejo continente se insiste en la importancia de conservar a los enfermos bien abrigados, 
el Dr. Vado indica que «en nuestro clima ardiente» la vestimenta debía ser ligera. En este mismo sentido expresa sus dudas sobre el uso de una franela en el vientre por temor a que «sea más perjudicial que provechoso en nuestro clima» (Vado, 1853).

\section{LA HERBOLARIA Y LA QUÍMICA AL SERVICIO DE LA MEDICINA}

En los métodos escritos y/o circulados en Yucatán se consigna que para combatir al cólera se emplearon diversas sustancias químicas, minerales o hierbas. Se aplicaban casi siempre en combinación con otras, diluidas en agua o alcohol, preparadas como medicamentos o en infusiones a base de distintos extractos. De hecho, en el siglo XIX la terapéutica estuvo estrechamente relacionada con los avances alcanzados en el ramo de la química que, desde el siglo anterior, estrechó sus conexiones con la medicina y la farmacéutica (Alegre y Gil, 1992, pp. 46-48). La carrera de medicina en Yucatán incluyó como una de sus mate- rias básicas la química, enfocada en parte a la terapéutica (Tabla 6). Sobre el abastecimiento de productos farmacoquímicos en Yucatán sabemos muy poco, pero es posible que muchos llegaran de Europa donde había laboratorios con científicos que trabajaban aislando sustancias activas (Alegre y Gil, 1992, p. 49-50). Otros, como el azufre, llegaron desde Florida, donde se descubrió el primer yacimiento en América y pronto comenzó a ser explotado con tecnología novedosa, tras decaer los yacimientos de Sicilia, principal proveedor hasta el siglo XVIII.

Hoy sabemos que muchas de estas sustancias tienen propiedades toxicológicas y/o narcóticas, y los efectos que producen bien podrían haberse confundido con los del cólera, como cólicos, vómito y diarrea (Bartomeu y Nieto, 2006, p. 105). Entre los narcóticos destaca la estricnina, sustancia altamente tóxica que en dosis cercanas a los $15 \mathrm{mg}$. puede provocar la muerte tan solo media hora después de haberla ingerido. Como alcaloide, servía para tratar el dolor y los fuertes

Tabla 6. Sustancias químicas empleadas como tratamiento contra el cólera en Yucatán, 1833, 1853.

\begin{tabular}{|c|c|c|c|c|}
\hline Denominación & Sustancia activa & Tipo & Efecto esperado & $\begin{array}{l}\text { Efecto conocido } \\
\text { actualmente }\end{array}$ \\
\hline $\begin{array}{l}\text { Extracto de Goulard o } \\
\text { extracto de Saturno }\end{array}$ & Acetato de plomo & Químico orgánico & Astringente, revulsivo & $\begin{array}{l}\text { Tóxico, astringente, } \\
\text { revulsivo }\end{array}$ \\
\hline Espíritu de alcanfor & Alcanfor & Químico orgánico & Revulsivo & $\begin{array}{l}\text { Revulsivo, anestésico, } \\
\text { antimicrobiano }\end{array}$ \\
\hline Flor de azufre & Azufre & Químico inorgánico & Revulsivo & Revulsivo \\
\hline Carbón molido & Carbón & Químico inorgánico & Revulsivo & $\begin{array}{l}\text { Propiedades } \\
\text { antidiarréicas, } \\
\text { inactiva toxinas y } \\
\text { microorganismos en el } \\
\text { tracto intestinal }\end{array}$ \\
\hline Cloroformo & Cloroformo & Químico orgánico & Calmante & Anestésico \\
\hline Calomel & Cloruro de mercurio & Químico inorgánico & Revulsivo, calmante & Revulsivo, tóxico \\
\hline Estricnina & Estricnina & $\begin{array}{l}\text { Químico orgánico } \\
\text { (alcaloide) }\end{array}$ & Revulsivo & $\begin{array}{l}\text { Revulsivo, pesticida, } \\
\text { tóxico }\end{array}$ \\
\hline Éter & Éter & Químico orgánico & & \\
\hline Magnesia & Magnesia & Químico inorgánico & Revulsivo & Revulsivo, antiácido \\
\hline Tintura de quinina & Quinina & $\begin{array}{l}\text { Químico orgánico } \\
\text { (alcaloide) }\end{array}$ & $\begin{array}{l}\text { Usado contra la } \\
\text { malaria }\end{array}$ & $\begin{array}{l}\text { Antipirético, } \\
\text { analgésico }\end{array}$ \\
\hline $\begin{array}{l}\text { Polvos de Sedliz o } \\
\text { Sales de Epsom }\end{array}$ & Sulfato de magnesio & Químico orgánico & Revulsivo & $\begin{array}{l}\text { Revulsivo, relajante } \\
\text { de los músculos } \\
\text { intestinales, } \\
\text { desinflamatorio }\end{array}$ \\
\hline Sales de Glauber & Sulfato de Sodio & Químico orgánico & $\begin{array}{l}\text { Revulsivo y } \\
\text { astringente }\end{array}$ & $\begin{array}{l}\text { Revulsivo y } \\
\text { astringente }\end{array}$ \\
\hline
\end{tabular}

Fuente: AGEY, Poder Ejecutivo, Correspondencia Oficial, Vol. 3, exp. 15; Canú, 1848; Descubrimientos contra el cólera, 1848; Disminución de los estragos, 1849; Foy, 1849; Quinn, 1850; Vado, 1853. 
calambres que se manifiestan con el cólera. Sus propiedades venenosas fueron reconocidas desde su descubrimiento a principios del siglo XIX, junto con otros alcaloides como brucina, morfina, emetina o keratina (Sánchez y Nieto, 2006, p. XVI). El Dr. Vado asegura haber utilizado estricnina desde 1833 (Vado, 1853).

La quinina era otro alcaloide empleado para combatir el cólera (Rivals, 1834, p. 61). Esta sustancia se obtiene de la corteza de la quina, árbol nativo de los bosques andinos que por cerca de tres siglos fue el único remedio con el que se trataba la malaria. En el siglo XVIII circulaban entre América y Europa extractos y tinturas de corteza de quina, pero no fue hasta 1820 que la quinina fue aislada como principio activo y posteriormente comercializada como medicamento industrializado (Alegre y Gil, 1992, p. 61; Amurrio, 2003, p. 241). Contra el cólera, se aconsejaba administrarse en la fase más crítica del desarrollo de la enfermedad ${ }^{27}$.

Dentro del rubro de alcaloides se encuentran los derivados del opio, sustancia narcótica muy empleada entonces por sus propiedades revulsivas y tranquilizantes. Si bien su principio más activo es la morfina, también incluye cantidades menores de codeína y narcotina. Desde el siglo XVIII se expendían en boticas distintas preparaciones con opio con las denominaciones de láudano o tintura tebáica. La fórmula más difundida de láudano en el siglo XIX era la del doctor ingles Sydenham (siglo XVII), que consistía en una tintura alcohólica de opio compuesta por vino blanco, azafrán, clavo, canela y otras sustancias, además de opio. Para tratar los cólicos característicos del cólera, el Dr. Ignacio Vado indicó 10 gotas de láudano diluidas en agua de arroz con un poco de almidón; el empleo de esta sustancia era tan común, que de acuerdo con este facultativo "este tratamiento es el que ha tenido mejores resultados" y se podía administrar sin la presencia de un profesional experto en la «administración de drogas» (Vado, 1853). Otros métodos que también circularon en Yucatán prescribieron esta sustancia para el tratamiento de cólicos en bebidas «ligeramente opiadas», con dos cucharadas de extracto de menta o aguardiente y cinco o seis gotas de láudano. De esta sustancia se dice que formaba parte de los medicamentos que «regularmente se utilizan para toda enfermedad de las entrañas cuando se advierten los primeros síntomas ${ }^{28}$. La tintura tebáica también era un medicamento preparado a base de opio. A diferencia del láudano, la tintura tebáica es prácticamente la única preparación referida por los curas de los pueblos de Yucatán durante la epidemia de 1833.

Asimismo, en las terapias revulsivas se sugería el uso de ciertas sustancias «de tanto uso en la higiene de los ingleses»: "sales de Glauber» compuestas por sulfato de sodio, sustancia conocida por sus propiedades astringentes y aceleradoras del tránsito intestinal; "sales de Epsom» y "polvos de Sedlitz», ambos sulfato de magnesio, con efectos laxantes, relajantes de los músculos intestinales y desinflamatorios ${ }^{29}$.

Además de las sustancias referidas, para el tratamiento del cólera se usaban también varias hierbas locales y foráneas que se administraban generalmente en infusiones, pero también mezcladas con harinas para cataplasmas y otras más como enemas (Tabla 7).

Algunas de estas especies botánicas se emplearon buscando efectos acordes con la misma lógica de la medicina humoral: revulsivos para purgar al cuerpo del exceso de humores, antiflogísticos para reducir la irritación, antiespasmódicos para relajar los músculos contraídos y estimulantes para devolver al cuerpo la vitalidad perdida. Otras más sirvieron como base para ser combinadas con otras sustancias químicas y/o narcóticas, como opio o cloroformo.

Dentro de las que se usaban como revulsivas o catárticas destacan ruibarbo, ipecuana, mostaza, pimienta y aceite de palma. Ninguna es una especie local, sino que provenían de Asia, África o Sudamérica y habían sido incorporadas a la farmacopea desde tiempo atrás. El ruibarbo, por ejemplo, es un poderoso purgante y estimulante de las funciones del estómago e hígado. Al igual que el clavo y la canela, se importaba desde China (Reyna, 2009), y en Yucatán era expendido en polvo por boticarios, empleándose como catártico para tratar diversas enfermedades (Osorio y Carvajal, 1977, p. 310). Originaria de Brasil, la ipecuana se utilizaba también como vomitivo. Fue introducida en la farmacopea europea desde el siglo XVII, y en el XIX México recibía este producto de La Habana. Las especies que se administraban como antiflogísticos eran hierbas aromáticas como menta, manzanilla, toronjil, hojas de naranjo, sábila y tila.

El cólera tenía como uno de sus síntomas principales espasmos y cólicos; se creía que los cólicos eran señal de un espasmo intestinal severo que conducía a una extinción súbita de la vitalidad (Valdez, 1835, p. 37). La consecuencia terapéutica de este esquema es lógica: incluir sustancias antiespasmódicas y calmantes a los procesos curativos. En la prensa local en Yucatán circulaba en 1833 la aseveración de que a pesar de ser el cólera un «mal temible», en todas partes se había comprobado que:

aplicados los remedios antiespasmódicos [...] se ha conseguido salvar un considerable número de individuos que hubieran sido víctimas en el caso contrario ${ }^{30}$. 
Tabla 7. Especies botánicas empleadas como tratamiento contra el cólera en Yucatán, 1833, 1853.

\begin{tabular}{|c|c|c|c|c|}
\hline Denominación & Nombre botánico & Uso & Efecto esperado & $\begin{array}{l}\text { Efecto conocido } \\
\text { actualmente }\end{array}$ \\
\hline Ruibarbo & Heum rhabarbarum & Infusión & Revulsivo & $\begin{array}{l}\text { Purgante, } \\
\text { desparasitante }\end{array}$ \\
\hline Mostaza & Brassica & $\begin{array}{l}\text { Infusión, cataplasmas, } \\
\text { sinapismos }\end{array}$ & Estimulante, revulsivo & Rubefaciente, \\
\hline Canela & \begin{tabular}{|l} 
Cinnamomum \\
zeylanicum
\end{tabular} & $\begin{array}{l}\text { Agua de canela horadada, } \\
\text { infusión }\end{array}$ & Estimulante por el olor & Estimulante \\
\hline $\begin{array}{l}\text { Menta/ } \\
\text { hierbabuena }\end{array}$ & Mentha spicata & Infusión & $\begin{array}{l}\text { Estimulante por el } \\
\text { olor, antiflogístico, } \\
\text { antiespasmódico }\end{array}$ & $\begin{array}{l}\text { Antiespasmódico, } \\
\text { analgésico }\end{array}$ \\
\hline Pimienta & Piper nigrum & Infusión, cataplasmas & Estimulante, catártico & Catártico \\
\hline Jengibre & Zingiber officinale & Cocimiento de la raíz & $\begin{array}{l}\text { Para calentar el cuerpo, } \\
\text { antiespasmódico }\end{array}$ & Antiespasmódico \\
\hline Granada & Punica granatum & Cocimiento de la cáscara & Para diarrea blanquecina & \\
\hline Palma & Elaeis guineensis & Aceite de palma & Revulsivo & \\
\hline Guaco & Mikania Laevigata & Jugo de las hojas y tallo & Antiespasmódico & $\begin{array}{l}\text { Antiespasmódico, } \\
\text { irritante }\end{array}$ \\
\hline Ipecuana & Carapichea ipecacuanha & Infusión & Revulsivo. & $\begin{array}{l}\text { Revulsivo, } \\
\text { expectorante, } \\
\text { diaforético }\end{array}$ \\
\hline Tabaco & Nicotiana tabacum & $\begin{array}{l}\text { Enemas de humo de } \\
\text { tabaco }\end{array}$ & Estimulante & \\
\hline Peyote & Lophophora williamsii & Cocimiento de la raíz & & \\
\hline Manzanilla & Matricaria chamomilla & Infusión & Antiflogístico & \\
\hline Toronjil & Melissa oficinalis & Infusión & Estimulante, antiflogístico & $\begin{array}{l}\text { Antiflogístico, } \\
\text { antiespasmódico }\end{array}$ \\
\hline Lechuga & thridace & Extracto de lechuga & Relajante, antiespasmódico & \\
\hline Naranja agria & Citrus auriantum L. & $\begin{array}{l}\text { Infusión de las hojas, } \\
\text { cocimiento de cogollos }\end{array}$ & $\begin{array}{l}\text { Antiflogístico, estimulante } \\
\text { para la recuperación final }\end{array}$ & \\
\hline $\begin{array}{l}\text { Sanguinaria/ } \\
\text { kantubub }\end{array}$ & & Infusión & $\begin{array}{l}\text { Sudorífico, para combatir } \\
\text { vómitos con sangre }\end{array}$ & \\
\hline Epazote & Dysphania ambrosioides & Infusión & $\begin{array}{l}\text { Para combatir la diarrea } \\
\text { blanquecina }\end{array}$ & \\
\hline Habanero & Capsicum chinense & Cocimiento & $\begin{array}{l}\text { Para combatir los vómitos con } \\
\text { sangre }\end{array}$ & \\
\hline Maíz & Zea mays & Agua de maíz & $\begin{array}{l}\text { Para combatir la diarrea } \\
\text { blanquecina }\end{array}$ & \\
\hline Tila & Tila cordata & Infusión & Antiflogístico & $\begin{array}{l}\text { Relajante, } \\
\text { antiespasmódico }\end{array}$ \\
\hline Sábila & Aloe vera & Infusión & Antiflogístico & \\
\hline Romero & Rosmarinus officinalis & Infusión & Antiflogístico & \\
\hline $\begin{array}{l}\text { Artemisa/sal } \\
\text { de ajenjos }\end{array}$ & Artemisa absinthium & Infusión & & $\begin{array}{l}\text { Contrarresta la } \\
\text { indigestión y el } \\
\text { dolor gástrico }\end{array}$ \\
\hline Chicalote & Argemone mexicana & Cataplasma & Contra el dolor de estomago & \\
\hline Ortiga & & Fricciones & Antiespasmódico, sudorífico & \\
\hline
\end{tabular}

Fuente: AGEY, Poder Ejecutivo, Correspondencia Oficial, Vol. 3, exp. 15; Canú, 1848; Descubrimientos contra el cólera, 1848; Disminución de los estragos, 1849; Foy, 1849; Quinn, 1850; Vado, 1853. 
Todas las sustancias con efectos narcóticos, como opio, cloruro de mercurio, quinina o estricnina se empleaban como coadyuvantes antiespasmódicos al «tranquilizar» el sistema nerviosos cerebral, al igual que el cocimiento de la raíz de jengibre, extracto de lechuga y jugo de hojas y tallo del guaco.

Este último es un bejuco originario de América del Sur, principalmente del actual Colombia. El conocimiento sobre sus propiedades se atribuye a la población de negros esclavos que "transmitían de unos a otros, acompañándole con rezos, ceremonias y actos supersticiosos». En la Colonia se empleaba como contraveneno en casos de mordedura de serpiente, aunque en el siglo XVIII se extendió su uso por Puerto Príncipe, Cuba y Veracruz para tratar diarreas crónicas y disentería. Su empleo en Yucatán a finales de la Colonia quedó registrado en el Libro de medicinas muy seguro ... de 1751 (Gubler, 2010). En el siglo XIX se producía en los campos de Veracruz, Tampico y Nueva Orleans. Se distribuía en boticas, ya fueran directamente tallos y hojas, o extractos embotellados hechos con alcanfor, aguardiente o éter.

Las especies empleadas en los pueblos de Yucatán en 1833 , según reportes de curas, eran plantas disponibles localmente, algunas de tradición indígena y otras procedentes de Europa pero que ya crecían en suelo yucateco: hierbabuena, granada, naranja agria, sanguinaria, epazote y chile habanero. Todas se empleaban desde la Colonia para curar diferentes dolencias, especialmente relacionadas con el estómago y la digestión. Es posible que de la herbolaria regional se emplearan más especies para tratar el cólera que las que aquí se refieren, pues las sustancias tan recomendadas en los distintos métodos curativos habrían sido de difícil acceso; al ser elementos químicos o plantas procedentes de Europa, Asia, África, u otras partes de México y América, sólo se expendían en las boticas existentes en la ciudad de Mérida o Campeche. Por otro lado, las fuentes de la herbolaria yucateca del siglo XVIII revelan una amplia, rica y variada gama de hierbas, plantas y otras sustancias (como arcilla, excremento de distintos animales o piedras bezares) utilizadas para tratar distintas patologías y padecimientos (cfr. Gubler, 2010).

\section{CONSIDERACIONES FINALES}

El estudio del proceso salud/enfermedad/atención en el Yucatán del siglo XIX a partir de las dos primeras epidemias de cólera, muestra una coyuntura importante en la que las ideas en torno a las enfermedades, su tratamiento y la administración y gestión de la salud pública se encontraban en proceso de secularización, sentándose las bases para la profesionalización y la práctica médica.
La terapéutica y la base lógica de los tratamientos es el terreno que nos permitió analizar la interrelación entre ideas y prácticas médicas, así como la imbricación y adaptación de hipótesis de la época y su expresión en el tratamiento de enfermedades. A grandes rasgos, encontramos que los pilares que sostuvieron la terapéutica para atender a los enfermos de cólera en Yucatán, se construyeron con las ideas entonces vigentes en Europa en torno a la salud y la enfermedad, particularmente en Francia. Estas ideas Ilegaron con los médicos que ejercieron en el estado y fueron formados en la Escuela de París, pero también se difundieron gracias a la prensa liberal que localmente hacia circular escritos dirigidos a público no especializado, retomando ideas publicadas originalmente en Europa o Estados Unidos.

Como en Europa, en Yucatán la teoría de los miasmas sirvió para explicar cómo una misma enfermedad atacaba a muchas personas, fortaleciendo las aprensiones empíricas respecto al vínculo entre basura, contaminación y enfermedad, tan patente en el cólera. A través de distintos mecanismos (respiración, ingestión, contacto directo, etc.), se pensaba que los miasmas provocaban un desbalance interno de humores, dañando órganos del cuerpo humano por irritación o inflamación. Si bien es cierto que la teoría humoral era entonces bastante antigua, en el siglo XIX la fisiología permitió a los médicos explicar el daño específico de los órganos y sus consecuencias en el funcionamiento general del mecanismo entero del cuerpo humano.

Se pensaba que el desbalance de humores provocado por el cólera, como veneno o fermento, generaba una irritación patológica en el estómago, y ello dañaba al resto de los organos del cuerpo y los hacía perder su vitalidad. La consecuencia terapéutica de este esquema de ideas fue el uso de técnicas revulsivas para volver a nivelar los humores, antiflogísticas para disminuir la irritación patológica y vitalistas (masajes, "friegas») para devolver a los órganos la vitalidad vulnerada. Para coadyuvar en estas terapias se utilizaban sustancias minerales y/o químicas expendidas en boticas locales, pero también de la herbolaria local a las que se podía acceder en prácticamente cualquier parte.

La terapéutica para tratar el cólera en Yucatán, registra asimismo un esfuerzo de los médicos para adaptar las técnicas recomendadas en Europa a las condiciones particulares del estado, como el clima o la alimentación, además de la adpoción de especies locales y la necesidad de que los enfermos fueran atendidos prontamente sin la necesidad de facultativos, tan escasos entonces. 


\section{NOTAS}

1. AGEY, Poder Ejecutivo, Correspondencia Oficial, Vol. 3, exp. 10, "1833. Correspondencia de autoridades de varios pueblos con el gobernador del Estado, 3 de abril al 16 de julio de $1833 "$.

2. Cuenya y Malvido apuntan que el cólera hizo obvia la supeditación de México a Estados Unidos en el proceso de globalización, pues la bacteria siguió el camino de las mercancías y los hombres que invadieron el país (Cuenya y Malvido, 1992, p. 12-13). Malvido, por su parte, asegura que a partir de 1833 "todos nuestros males entran a pie por la frontera norte y el cólera morbus reaparece casualmente con el libre comercio, 1833, 1993" (Malvido, 2006, p. 147).

3. CAIHY, X-1853-18 [Manifestación a los habitantes de Yucatán] [folletería] / Su gobernador y comandante general Rómulo Díaz de la Vega, E. López Secretario.

4. La bacteria del cholera fue aislada por primera vez por el médico alemán Robert Koch en 1883 (Magner, 2002, 268).

5. Estos autores plantean que la dicotomía frío/calor presente en la medicina indígena contemporánea deriva de una degeneración de la teoría humoral que fue difundida en suelo Americano por los españoles; en contraste López Austin (1996, pp. 303-318) considera que esta dualidad es de origen americano, porque no se reduce al campo se la salud, la enfermedad y la medicina, sino que comprende todo el cosmos y existe una imbricación de los poderes del cosmos con la enfermedad; y porque existen menciones muy antiguas sobre este sistema.

6. Sobre la idea de que el cólera era un veneno o fermento emanado a la atmósfera que dañaba el funcionamiento de los órganos alterando su fuerza vital, cfr. (Rivals, 1834, p. 11; Foy, 1849).

7. AGEY, Justicia, Serie Civil, Sección Alcaldía de primera instancia de lo civil, Subserie Testamentos, Vol. 14, exp. 1, El Baluarte de la Libertad (No. 94, Vol. 1), julio 6 de 1833.

8. "Disminución de los estragos del cólera morbus", 1848. Este argumento difundido en Yucatán también se puede leer en el semanario El Baluarte de la Libertad, julio 6 de 1833.

9. Sobre la falta de higiene en Mérida en 1833 y su asociación con el cólera, cfr. El Baluarte de la Libertad (No. 94, Vol.1), julio 6 de 1833.

10. Sobre la fiebre amarilla en Yucatán en el siglo XIX cfr. (Bustamante, 1994; Menéndez, 1981, p. 166; Alcalá, 2012). Sobre viruela cfr. (Alcalá, 2009). Sobe el cólera cfr. (Dondé, 1920; Laviada, Laviada y Puga, 1993; Rubio y Tzuc, 1995; Alcalá 2013; Peniche, 2013; Malvido y Peniche, 2013).

11. Esta comisión se formó además con el Dr. Juan Hübbe (de Alemania), el Dr. Sebastián Sotomayor (de España) y Enrique Perriné (de Francia), (Álvarez, 1912, p. 254).
12. CAIHY XXVI -1833-2/2-012 [Constancia de la toma de posesión de la cátedra de cirugía plástica y medicina al Dr. Ignacio Vado] [manuscritos] / José María Meneses, Pedro Almeida, Ignacio Vado.

13. Como evidencia del empleo de terapias revulsivas en Yucatán cfr. "Remedios preservativos y curativos contra el cólera morbus" (Campeche, 1849); "Remedios preservativos y curativos del Dr. Canú", (Campeche, 1848); "Método curativo contra el cólera" del Dr. Ignacio Vado, (Mérida, 1853).

14. CAIHY, LMEP-024, [Libro de actas de cabildo]/Altares, Mugartegui, 1833.

15. CAIHY, LMEP-024...

16. CAIHY, LMEP-058 [Libro copiador de correspondencia de Cabildo] / Vicente M, 1853.

17. Método preservativo y curativo, 1833.

18. Método preservativo y curativo, 1833.

19. Para enfermedades mentales, ver por ejemplo Ramos de Viesca et.al, 2002.

20. CAIHY, 348.7265 A96 1849 t. 1 -- 1 29. Colección de leyes, decretos, órdenes o acuerdos de tendencia general del Poder Legislativo del Estado Libre y Soberano de Yucatán / Alonso Aznar Pérez, Rafael Pedrera.

21. Sobre la "medicina tradicional" maya en la época colonial, cfr. Chávez, 2013.

22. AGEY, Poder Ejecutivo, Correspondencia Oficial, Vol. 3, exp. 15, "1833. Cólera morbus. Correspondencia de varios funcionarios de los pueblos con el gobernador del Estado con informes de la epidemia del cólera morbus. Julio 30 de 1833".

23. AGEY, Poder Ejecutivo, Correspondencia Oficial, Vol. 3, exp. 15 ...

24. AGEY, Poder Ejecutivo, Correspondencia Oficial, Vol. 3, exp. 15 ...

25. El Balear. Periódico de la tarde, Mallorca, sábado 23 de septiembre de 1848

26. CAIHY XXVI -1833-2/2-012 [Constancia de la toma de posesión de la cátedra ...

27. Prevenciones higiénicas y método curativo, 1866, p. 22-23.

28. "Disminución de los estragos del cólera morbus", 1848.

29. En: "Disminución de los estragos del cólera morbus", 1848. Sobre composiciones y efectos cfr. (Jourdan, 1839, t. 2, p. 165; Sánchez y Belmar, 2006, pp. 119-120).

30. El Baluarte de la Libertad (No. 94, Vol. 1), julio 6 de 1833. 


\section{Fuentes}

s.d. (1832), Diario General de las Ciencias Médica o Colección periódica de noticias y discursos relativos a la medicina y ciencias auxiliares, tomo séptimo, Barcelona, Imprenta de J. Verdaguer.

s.d. (1833), Método preservativo y curativo de la Colera morbus epidémica que la Junta de Sanidad erigida al intento en la Capital del Estado eleva al gobierno del mismo para su publicación, Imprenta del Estado en Palacio a cargo del Ciudadano José María Infante, San Luis Potosí, [en línea], disponible en: https://archive.org/details/64750080R.nIm.nih.gov

s.d. (1849), Precauciones para librarse del cólera-morbo asiático y método curativo extendido en junta general de los médicos existentes en esta capital por disposición del Honorable Congreso y por conducto del Gobierno del Estado. Descripción del cólera-morbo asiático. Método curativo para el caso en que no pueda ocurrirse a un médico. Precauciones para librarse de él cuanto sea posible, Tipología Pérez, Querétaro.

s.d. (1866), Prevenciones Higiénicas y Método curativo del Cólera-Morbo, Consejo de Salubridad de Nuevo León, Nuevo León.

Álvarez, Francisco (1912), Anales Históricos de Campeche, 1812 a 1910, Vol. 1, Mérida, Imp. del Colegio San José de Artes y Oficios.

Broussais, Francois Joseph Victor (1832), La Cólera-morbus epidémica observada y tratada según el método fisiológico y relación de las epidemias de la cólera-morbus observada en Hungría, Moldavia, Galicia, en los años de 1831 y 1832, París, impr. De Decourchant.

Canú, Dr. (1848), Remedios preservativos y curativos contra el cólera Morbus, Campeche, impr. Joaquín Castillo Peraza.

Castillo Peraza, Joaquín (1899), Artículos sueltos, Mérida, Tipografía de $\mathrm{G}$. Canto.

Cruxent, C. (1850), El cólera, la homeopatía y la alopatía, o sea, reglas higyénicas, profilácticas y curativas, La Habana, Imprenta de la Real Sociedad Económica a cargo de D. Antonio Martínez.
Febles, Manuel de Jesús (1833), Cartilla Vulgar para conocer y curar la Cholera-Morbus con lo que se a esperimentado los mejores resultados dispuesta de orden del Supremo Gobierno, México, Impresa por el ciudadano Agustín Guiol.

Fernández Valle, Juan (1794), Tratado de la flebotomía u operación de la sangría, Madrid, Oficina de Cruzado.

Foy, Dr. (1849), “El cólera-morbus. Primeros socorros que deben ministrarse a los coléricos antes de la llegada del médico, procedidos de una indicación precisa de los síntomas de la enfermedad, y seguidos de una exposición sencilla y rápida de los medios higiénicos y profilácticos que puedan impedir su ataque", El Fénix, Campeche, miércoles 5 de septiembre de 1849, número 62; 10 de setiembre, número 63; 15 de septiembre, número 64; 20 de setiembre, número 65; 25 de setiembre, número 66 .

Jiménez, Lauro María (1856), “Apuntes sobre algunas especies de sanguijuelas de México", Gaceta Médica de México, Tomo I, Núm. 30, diciembre de 1856.

Jourdan, A.J.L. (1939), Farmacopea Universal o reunión comparativa de las farmacopeas, Madrid, Imprenta de Fuentenebro, Tomo II.

López Soler, D.R. (1831), Del cólera-morbo, Valencia, Imprenta de José de Orga.

Rivals, D.M.M. (1834), El cólera-Morbo combatido por los medios mas probados y seguros, o sea instrucción práctica sobre los métodos preservativos y curativos que han obtenido mas felices resultados particularmente sobre los que han sido publicados por orden de los gobiernos español y francés. El cólera es más espantoso de lejos que peligroso de cerca. Instrucción de la comisión central de sanidad de Francia, Barcelona, Imprenta de J. Oliviers.

Vado, Ignacio (1853), Método curativo contra el cólera morbo, sin necesidad de médicos botica, Mérida, Mariano Guzmán.

Valdez, José Manuel (1835), Memoria sobre la disentería, sus causas, pronóstico y curación, Lima, Imprenta de la Gaceta por José Masías. 


\section{BIBLIOGRAFÍA}

Alborn, Timothy (2001), "Insurance against Germ Theory: Commerce and Conservatism in Late-Victorian Medicine", Bulletin of History of Medicine, 75, pp. 406-445.

Alcalá Ferráez, Carlos Ramón (2008), Asistencia, sanidad y población en la ciudad de San Francisco de Campeche, tesis de doctorado. Universidad de Barcelona.

Alcalá Ferráez, Carlos Ramón (2009), “La viruela en el Estado de Campeche, 1875", Naveg@mérica. Revista electrónica de la Asociación Española de Americanistas, (3), [en línea], disponible en: http://revistas.um.es/navegamerica, [consultado el 20/03/2014].

Alcalá Ferráez, Carlos Ramón (2012), “De miasmas a mosquitos: el pensamiento médico sobre la fiebre amarilla en Yucatán, 1890-1920", Histórica, Ciencias, Saúde-Manguinhos, Río de Janeiro, 19 (1), enero-marzo, pp. 71-87.

Alcalá Ferráez, Carlos Ramón (2013), “Cólera: mortalidad y propagación en la península de Yucatán, 1833-1834”, Letras Históricas, otoño 2012-invierno 2013, (7), pp. 115-141.

Alegre Pérez, María Esther y María Esther Gil Alegre, (1992) La farmacia en el siglo XIX, Colección Akal, Historia de la Ciencia y de la Técnica no 47. Madrid, Akal.

Amezcua Martínez, Manuel (1997), “Barberos y sangradores flebotomianos en Granada: norma y sociedad en los siglos XVII y XVIII", Cultura de los cuidados, 1 (1), pp. 31-36.

Amurrio, David (2003), "La quinina. Historia y síntesis", Acta Nova, 2 (3), diciembre, pp. 241-247.

Arquiola, Elvira (1992), "La formulación de una teoría general de la enfermedad en Francia en el tránsito del siglo XVIII al XIX", DYNAMIS Acta Hispánica ad Medicinae Scientiarumque Histosiam Illustrandam, 12, pp. 189-208, [en línea], disponible en: http://ddd.uab.cat/record/34621.

Ávila Escalante, Álvaro (1977), “Historia de la medicina alopática en la época colonial"., Enciclopedia Yucatanense, 4, Mérida, Gobierno del Estado de Yucatán, pp. 261-284.

Baldwin, Peter (2004), Contagion and the State in Europe 18301930. Cambridge University Press.

Bartomeu Sánchez, José Ramón y Antonio García Belmar (2006), La revolución química. Entre la historia y la memoria. Universidad de Valencia.

Bartomeu Sánchez, José Ramón y A. Nieto Galán (2006), Entre la ciencia y el crimen: Mateu Orfila y la toxicología en el siglo $X I X$. Barcelona, Fundación Esteve.

Bourdelais, Patrice (2006), Epidemics laid low: a history of what happened in rich countries. Baltimore, The Johns Hopkins University Press.
Briggs, Asa (1961), "Cholera and Society in the Nineteenth Century", Past and Present, 19 (1), pp. 76-96.

Bustamante, Miguel E. (1994), "Pasado, presente y futuro de la epidemiología”, Salud Pública Mex, 36 (1), pp. 97-112.

Buzzi, Alfredo (1968), Evolución histórica de la medicina clínica. Universidad de Buenos Aires.

Campos-Navarro, Roberto (1997), "Curanderismo, medicina indígena y proceso de legalización", Nueva Antropología, XXI (53), pp. 67-87.

Carrillo, Ana María (2001), "Los comienzos de la bacteriología en México", Elementos: ciencia y cultura, junio-agosto, 8 (42), Benemérita Universidad Autónoma de Puebla, pp. 2327.

Cervera Andrade, Alejandro (2002), “Breve historia de la cirugía en Yucatán", Revista Biomédica, 13 (2), pp. 144-151.

Chávez Guzmán, Mónica (2013), Cuerpo, enfermedad y medicina en la cosmología maya del Yucatán colonial. México, UNAM.

Cipolla, Carlo M. (1993), Contra un enemigo mortal e invisible. Barcelona, Ed. Crítica.

Corbin, Alain (1987), Del perfume o el miasma. El olfato y lo imaginario social. Siglos XVIII y XIX. México, Fondo de Cultura Económica.

Cuenya, Miguel Ángel y Elsa Malvido (1992), “La pandemia de cólera de 1833 en la ciudad de Puebla". En: Miguel Ángel Cuenya; Elsa Malvido y Concepción Lugo O (coords.), El cólera de 1833: una nueva patología en México. Causas y efectos, México, INAH, pp. 11-47.

Dondé, Lorenzo Efrem (1920), "El cólera morbus en la Península de Yucatán en 1833", La Revista de Yucatán, Mérida, septiembre (68), p. 13.

Duby, Georges (1995), Año 1000, año 2000. La huella de nuestros miedos. Santiago de Chile, Ed. Andrés Bello.

Erosa Barbachano, Arturo (1997), La escuela de Medicina de Mérida Yucatán. Mérida, Universidad Autónoma de Yucatán.

Evans, Richard J. (1988), "Epidemics and Revolutions: Cholera in Nineteenth-century Europe", Past and Present, 120 (1), pp. 123-146.

Expósito González, Raúl (2011), “Barberos y sangradores en Iberoamérica”, Cultura de los cuidados, XV (29), pp. 31-46.

Foster, George M. (1987), "On the Origin of Humoral Medicine in Latin America", Medical Anthropology Quaterly, diciembre, 1 (4), pp. 355-393. 
Gubler, Ruth (editora) (2010), Fuentes herbolarias yucatecas del siglo XVIII. El libro de medicinas muy seguro y cuaderno de medicinas. México, Colección Documentalia, UNAM.

Haggard, Villasana J. (1937), “Epidemic Cholera in Texas, 18331834", The Southwestern Historical Quaterly, 40 (3), pp. 216230.

Howard-Jones, Norman (1972), "Cholera Therapy in the Nineteenth Century", The Journal of the History of Medicine, XXVII (4), pp. 373-395.

Kiple, Kenneth F. (1985), "Cholera and race in the Caribbean", Journal of Latin American Studies, 17(1), pp. 157-177.

Laviada Arrigunaga, Francisco; Eduardo Laviada Arrigunaga y Alvaro H. Puga Navarrete (1993), "El cólera en la Península de Yucatán en el siglo pasado”, Rev. Biomed, 4 (1), pp. 43-48.

Laín Entralgo, Pedro (1978), Historia de la medicina. Barcelona, Salvat.

López Austin, Alfredo (1996), Cuerpo humano e ideología. Las concepciones de los antiguos nahuas, vol. I. México, UNAM.

Magner, Louis (2002), A History of the Life Sciences. Nueva York, Dekker.

Malvido, Elsa (2006), La población. Siglos XVI al XX. México, Océano/UNAM.

Malvido, Elsa y Paola Peniche Moreno (2013), "Los huérfanos del cólera morbus en Yucatán, 1833", Historia Mexicana, LXIII (1), pp. 111-170.

Márquez Morfin, Lourdes (1992), “El cólera en la ciudad de México en el siglo XIX", Estudios Demográficos y Urbanos, 19, pp. 77-93.

Mata Jiménez, Leonardo de Jesús (1992), El cólera: historia, prevención y control, San José Costa Rica, Editorial Universidad Estatal a Distancia- Editorial de la Universidad de Costa Rica.

Menéndez, Eduardo L. (1981), Poder, estratificación y salud: análisis de las condiciones sociales y económicas de la enfermedad en Yucatán, Ediciones de la Casa Chata, México, CIESAS.

Menéndez, Eduardo L. (1994), "La enfermedad y la curación ¿qué es la medicina tradicional?", Alteridades, 4, no. 7, pp. 71-83.

Menéndez, Eduardo (2009), De sujetos, saberes y estructuras. Introducción al enfoque relaciona en el estudio de la salud colectiva, Buenos Aires, Editorial Lugar.

Miqueo Miqueo, Consuelo (1987), "La introducción de la obra de F.J.V Broussais en España. Estudio Bibliométrico", Acta Hispanica Scientiarumque Historiam Illustrandam, vol. 7-8, pp. 171-185.
Netzahualcoyotzin Méndez, Marciano (2011), “Mortalidad sin crisis demográfica: el cólera de 1833 y 1850 en Tlaxcala", Tesis de doctorado en Humanidades, México, UAM-I.

Ortiz Monasterio, José (2004), "Agonía y muerte del Protomedicato de la Nueva España, 1831. La categoría socioprofesional de los médicos", Historias, 57, México, pp. 35-50.

Osorio y Carvajal, Ramón (1977), "Historia de la medicina alopática en la época independiente", Enciclopedia yucatanense, t. IV, Mérida, Gobierno del Estado de Yucatán, pp. 285-341.

Palmer, Steven (2003), From Popular Medicine to Medical Populism. Doctors, Healers and Public Power in Costa Rica, 18001940, Durham, Duke University Press.

Peniche Moreno, Paola (2013), "La casa reconstruida: Los sobrevivientes del cólera de 1833 y la recomposición familiar. Parroquia de Ixil, Yucatán", en: Molina del Villar, América; Márquez Morfin, Lourdes; Pardo, Claudia (ed.), El miedo a morir. Endemias, epidemias y pandemias en México: Análisis de larga duración, México, CIESAS/Instituto Mora/Universidad Autónoma de Puebla/CONACyT, pp. 205-220.

Pérez-Tamayo, Ruy (1988), El concepto de enfermedad. Su evolución a través de la historia, (2 tomos), México, CONACYT, UNAM, FCE.

Ramos de Viesca, María Blanca, Andrés Aranda Cruzalta, et.al (2002), "La sangría como recurso terapéutico en las enfermedades mentales en el México del siglo XIX", Salud Mental, vol. 25, No. 6, Diciembre, pp. 53-58.

Reyna, María del C. (2009), "Boticas y boticarios. Siglos XVI al XIX": Dimensión antropológica (revista en línea), No. 7, Instituto Nacional de Antropología, México, (URL: www.dimensionantropologica.inah.gob. $\mathrm{mx} / \mathrm{p}=1458$.

Rodriguez, Martha Eugenia (2001), "Los estudios médicos en México. Periodo virreinal y siglo XIX", Bol Mex His Fil Med, 4(2), pp. 16-22.

Rodríguez Flores, M. Pilar y Pilar Antonia (1997), “El desarrollo de un marco jurídico y la epidemia de Cólera de 1833", Noroba 14 Revista de Historia, Cáceres, pp. 127-135.

Rodríguez de Romo, Ana Cecilia (2000), "Fisiología mexicana en el siglo XIX: la enseñanza", Asclepio, Vol. LII-1-2000, pp. 217-223.

Rolleston, J.D. (1939), “F.J.V. Broussais (1772-1838): His Life and Doctrines", Proceedings of the Royal Society of Medicine, Section of the History of Medicine, January 11, vol. XXXII, pp.405- 413

Rosen, George (2005), De la policía médica a la medicina social, México, Siglo Veintiuno Editores.

Rosenberg, Charles E. (1962), The Cholera Years. The United States in 1832, 1849 and 1866, Chicago, The University of Chicago Press. 
Rubio Canul, Manuel y Lizbeth Tzuc Sánchez (1995), "24 horas para morir: epidemia de cólera morbo en Yucatán en 1833", Revista Biomed, 6, pp. 102-107.

Stevens, Donald F. (2006), “Eating, Drinking and Being Married: epidemic Cholera and the Celebration of Marriage un Montreal and México City, 1832-1833", The Catholic Historical Review, Vol. 92, No. 1 (Jan 2006), pp. 74-94.

\section{SIGLAS}

AGEY: Archivo General del Estado de Yucatán.

CAIHY: Centro de Apoyo a la Investigación Histórica de Yucatán.
Vera, C., Blu A., Torres, M. (2005), “Sanguijuelas, parásitos presentes ayer y hoy", Revista Chilena de Infectologia, 22(1): 32-37.

Zavala, María del Carmen (2007), "El cólera en Michoacán y la federalización de las políticas sanitarias en el siglo XIX", Tzintzun. Revista de Estudios Históricos, julio-diciembre, número 046, Universidad Michoacana de San Nicolás de Hidalgo, Morelia, pp. 39-88. 